\title{
Effects of Canopy and Micro-irrigation under the Trees on Spatial Variations of Soil Labile Phosphorus and Metals in a Citrus Grove
}

\author{
Zhenli He, ${ }^{1}$ David. V. Calvert, and Peter. J. Stoffella \\ University of Florida, Institute of Food and Agricultural Sciences, Indian River \\ Research and Education Center, 2199 S. Rock Rd., Fort Pierce, FL 34945-3138 \\ Mingkui Zhang \\ College of Natural Resource and Environmental Sciences, Zhejiang University, \\ Huajiachi Campus, Hangzhou 310029, P.R. China
}

Additional index words. canopy, citrus grove, leaching, emitter, heavy metals, phosphorus

Abstract. To evaluate effects of canopy and micro-irrigation under trees on accumulation and leaching of phosphorus (P) and heavy metals in agricultural sand soils, the horizontal and vertical variations of soil $P$ and metals in $a 408-\mathrm{m}^{2}$ plot within a grove under grapefruit (Citrus paradisi Macf.) production near Fort Pierce, Fla., was examined. A high horizontal variation of labile soil $P$ and metal concentrations was observed. Across the row, the highest values of $\mathbf{p H}, \mathbf{E C}$, water-soluble $\mathrm{P}$, and all metals occurred in the soils under the canopies, and the lowest values occurred in the soils near the water furrow or the midway of the inter-row. Along the grapefruit row, the highest values of many measured variables occurred along the northern side of the citrus tree and close to the emitter. The downward movement of $\mathrm{P}, \mathrm{Cu}$, and $\mathrm{Zn}$ in the soils was more significant in the soils in open areas (near the water furrow and midway of inter-neighboring trees) than those under the canopies. The differences in labile $\mathbf{P}$ and metal spatial distributions in the soils were related to the location of emitter fertigation and differences in rainfall-induced leaching in the field. The results suggest that applying fertilizers to sites under the canopy rather than the spaces between the trees can minimize leaching losses of nutrients.

Sandy soils, which are the dominant soil type for citrus production in Florida, have the disadvantages that mobile nutrients are readily leached by heavy rain or over-irrigation and a very small amount of water can be retained. Therefore, fertilization and irrigation management are critical for commercial citrus production on these soils. Repeated applications of fertilizers or metals-containing pesticides often lead to elevated soil $\mathrm{P}$ and trace metals (Alva, 1992; Stanley et al., 1995). Phosphorus and trace metal losses in the surface and subsurface runoff from agriculture to surface waters or groundwater increase with increasing soil $\mathrm{P}$ and trace metal levels (Heckrath et al., 1995; Sharpley, 1995; Moore et al., 1998). The fate of the $P$ and heavy metals also depends on water movement in soil. Plant cover could change the distribution of rain, and thus affect water movement in the soils. Plant canopy can effect the distribution of rainfall and soil moisture and soil properties (Challinor, 1968; Saffigna et al., 1976; Parker and Muller, 1982; Parkin and Codling, 1990; Moody and Jones, 2000). Citrus plant canopies intercept rain and alter the spatial distribution of water flux, thus

Received for publication 1 July 2002. Accepted for publication 23 Sept. 2003. This study was funded in part by DEP projects (DEP contract WM746 and SP 566). Florida Agricultural Experiment Station journal series R-08849.

${ }^{1}$ To whom requests for reprints should be addressed; e-mail zhe@mail.ifas.ufl.edu. resulting in spatial variation of the nutrient and pesticide leaching potential (Alva et al., 1999). Fertilizers in citrus groves are commonly applied by a broadcast spreader or through emitter fertigation. The emitter fertigation was usually applied in a limited area. It was hypothesized that both canopy and emitter irrigation influence the accumulation and movement of $P$ and metals in the soils. However, most studies of canopy effect on soil properties have been conducted on forest trees or field crops (Moody and Jones, 2000; Parker and Muller, 1982). In addition, the soil properties measured in these studies were primarily organic matter, biomass, moisture, nitrogen, and $\mathrm{pH}$ (Belsky et al., 1993; Berger and Glatzel, 1998; Callaway, 1990; Dolan et al., 2001; Hook et al., 1994; Moody and Jones, 2000; Ostertag, 1998). Minimal information exists regarding citrus canopy effects on the concentrations of $\mathrm{P}$ and heavy metals in soils within a citrus field. The objective of this study was to investigate the variability of soil labile $\mathrm{P}$ and metals in a citrus grove, which is important for assessing the leaching losses of $\mathrm{P}$ and heavy metals.

\section{Materials and Methods}

This study was conducted on a $408 \mathrm{~m}^{2}(68 \times 6 \mathrm{~m})$ plot in a com- mercial citrus grove in Fort Pierce, Fla., with 20-year-old white 'Marsh' grapefruit (Citrus paradist MacFadyen.) trees that have a canopy diameter of $\approx 3.6 \mathrm{~m}$. The trees were planted in north-south rows with a planting distance of 4 $\times 6 \mathrm{~m}^{2}$ on double-row raised beds to facilitate drainage for the tree root system. Bed height was $\approx 40$ to $50 \mathrm{~cm}$ above the bottom of the water furrow. The plot is nearly flat ( $<2 \%$ slope). The soil series was Wabasso sand (sandy, siliceous, hyperthermic alfic Alaquod). Mean clay and organic $\mathrm{C}$ were 41 and $4.7 \mathrm{~g} \cdot \mathrm{kg}^{-1}$, respectively. Historically, annual amounts of N, P, and K application averaged 165,37 , and $95 \mathrm{~kg} \cdot \mathrm{ha}^{-1}$, respectively. In October and February, $70 \%$ of the $\mathrm{P}$ was applied in the grove with dry broadcast; $\mathrm{N}, \mathrm{K}$ and the remaining $\mathrm{P}$ were applied by emitter fertigation. Emitter spray reaches an area with a diameter of $2 \mathrm{~m}$. Irrigation averaged $8 \mathrm{~h} /$ week at a rate of $37.8 \mathrm{~L} \cdot \mathrm{h}^{-1}$ during the dry season. In addition to application of $\mathrm{N}, \mathrm{P}$, and $\mathrm{K}$, both micronutrient fertilizers (annual foliar application of $\mathrm{Cu}$ and $\mathrm{Zn}$ ranged from 2.2 to $5.6 \mathrm{~kg} \cdot \mathrm{ha}^{-1}$ as copper sulfate, 2.2 to $4.5 \mathrm{~kg} \cdot \mathrm{ha}^{-1}$ as zinc sulfate, or 0.8 to $1.1 \mathrm{~kg} \cdot \mathrm{ha}^{-1}$ as chelated zinc), and $\mathrm{Cu}-$ and $\mathrm{Zn}$ - containing pesticides/ fungicides (such as copper hydroxide) were also routinely applied, which accelerate $\mathrm{Cu}$ and $\mathrm{Zn}$ accumulation in the soils. Mean annual rainfall in the grove is $1250 \mathrm{~mm}$. Rainfall varied seasonally, and most of the rainfall occurred from May to October.

Soil samples were collected in September 2001 using a 5-cm-diameter cylindrical soil auger. Four sampling patterns were followed. 1) A transect along the direction of the citrus tree row: three surface soils $(0$ to $5 \mathrm{~cm})$ were collected from each inter-tree space along a 68-m-long citrus tree row with a total of 51 samples collected. The interval of two neighboring sampling points was $1.33 \mathrm{~m}$. The three samples for each inter-tree space were distributed respectively on the north side of the tree (position A, close to emitter), midway between two neighboring tree (position $\mathrm{B}$ ), and on the south side of tree (position C) (Fig. 1). 2) Transects across the direction of the citrus row: eight $0-5 \mathrm{~cm}$ surface soils (L1, L2, L3, L4, L5, L6, L7, and L8, as

Fig. 1. Scheme of the soil sampling points (+ represents the emitter position).

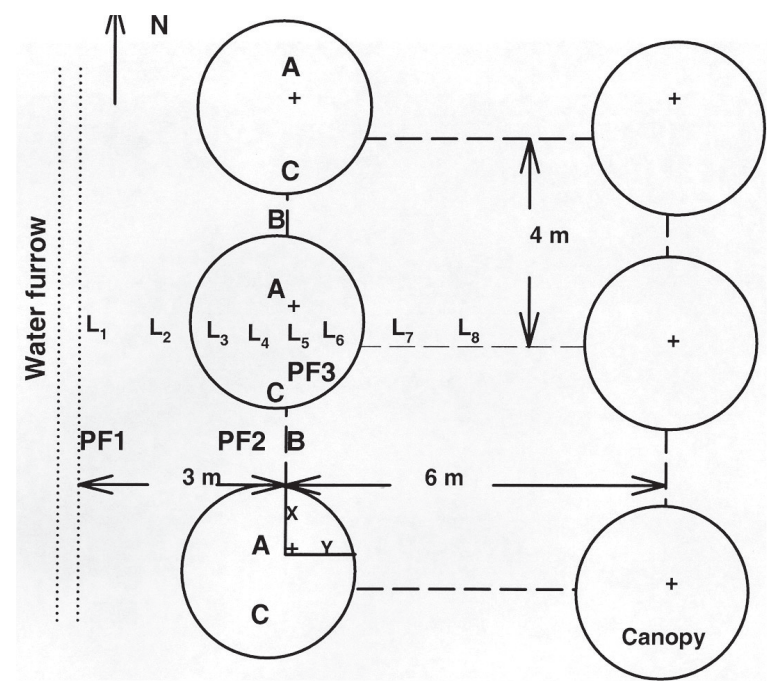

HortScience Vol. 39(3) June 2004 
Table 1. The maximum, minimum, mean values, and coefficients of variation ( $\mathrm{Cv}$ ) of $\mathrm{pH}$, electrical conductivity (EC), water-soluble, and Mehlich-III extractable P and metals in the surface soils $(\mathrm{n}=102){ }^{2}$

\begin{tabular}{lccc}
\hline Variable & Range & Mean & Cv $(\%)$ \\
\hline $\mathrm{pH}$ & $6.18-8.04$ & 7.20 & 5.4 \\
$\mathrm{EC}\left(\mu \mathrm{S} \cdot \mathrm{cm}^{-1}\right)$ & $49.4-511$ & 159 & 58.4 \\
Water-soluble & & & \\
$\mathrm{P}\left(\mathrm{mg} \cdot \mathrm{kg}^{-1}\right)$ & $2.47-20.6$ & 6.32 & 47.2 \\
$\mathrm{Ca}\left(\mathrm{mg} \cdot \mathrm{kg}^{-1}\right)$ & $1.84-84.8$ & 13.6 & 95.4 \\
$\mathrm{Mg}\left(\mathrm{mg} \cdot \mathrm{kg}^{-1}\right)$ & $0.44-26.6$ & 3.72 & 102 \\
$\mathrm{~K}\left(\mathrm{mg} \cdot \mathrm{kg}^{-1}\right)$ & $0.80-25.3$ & 2.83 & 103 \\
$\mathrm{Na}\left(\mathrm{mg} \cdot \mathrm{kg}^{-1}\right)$ & $2.92-16.3$ & 6.01 & 39.6 \\
$\mathrm{Cu}\left(\mathrm{mg} \cdot \mathrm{kg}^{-1}\right)$ & $0.21-11.2$ & 1.15 & 106 \\
$\mathrm{Zn}\left(\mathrm{mg} \cdot \mathrm{kg}^{-1}\right)$ & $0.18-1.37$ & 0.40 & 52.5 \\
$\mathrm{Fe}\left(\mathrm{mg} \cdot \mathrm{kg}^{-1}\right)$ & $0.49-13.8$ & 2.55 & 88.2 \\
$\mathrm{Mn}\left(\mathrm{mg} \cdot \mathrm{kg}^{-1}\right)$ & $0.02-2.71$ & 0.79 & 99.2 \\
$\mathrm{Cr}\left(\mu \mathrm{g} \cdot \mathrm{kg}^{-1}\right)$ & $0-44.4$ & 10.92 & 82.6 \\
$\mathrm{Ni}\left(\mu \mathrm{g} \cdot \mathrm{kg}^{-1}\right)$ & $0-57.4$ & 8.48 & 102 \\
$\mathrm{~Pb}\left(\mu \mathrm{g} \cdot \mathrm{kg}^{-1}\right)$ & $0-195$ & 29.3 & 133 \\
$\mathrm{As}\left(\mu \mathrm{g} \cdot \mathrm{kg}^{-1}\right)$ & $0-137$ & 12.7 & 152 \\
$\mathrm{Se}\left(\mu \mathrm{g} \cdot \mathrm{kg}^{-1}\right)$ & $0-50.2$ & 13.4 & 114 \\
$\mathrm{Mehlich} \mathrm{III-extractable}$ & & & 53.5 \\
$\mathrm{P}\left(\mathrm{mg} \cdot \mathrm{kg}^{-1}\right)$ & $36.3-337$ & 143 & 45.3 \\
$\mathrm{Cu}\left(\mathrm{mg} \cdot \mathrm{kg}^{-1}\right)$ & $23.9-156$ & 70.8 & 42.0 \\
$\mathrm{Zn}\left(\mathrm{mg} \cdot \mathrm{kg}^{-1}\right)$ & $7.60-71.8$ & 35.3 & 44.4 \\
$\mathrm{~Pb}\left(\mathrm{mg} \cdot \mathrm{kg}^{-1}\right)$ & $1.06-7.49$ & 2.86 & \\
\hline
\end{tabular}

${ }^{2}$ Surface samples included samples from the first three sampling patterns.

shown in Fig. 1) were collected along a transect from water furrow to midway of the inter-row (perpendicular to the water furrow), with a $75-\mathrm{cm}$ sampling interval. Position L4 was the nearest to the tree trunk. A total of four replicate transects were chosen. 3) A systematic sampling pattern near a emitter where two sets of 0 to $5 \mathrm{~cm}$ surface soils (each including 10 samples with interval of $10 \mathrm{~cm})$ were collected at varying distances from the emitter along two directions $(\mathrm{X}$, along the row; Y, perpendicular to the row, as shown in Fig. 1). 4) Duplicate profiles (PF1, PF2, and PF3, Fig. 1) were collected from near the water furrow, midway of the inter-neighboring tree, and under the canopy. Sampling depths were 0-5, 5-10, 10-20, 20-30,30-40,40-60, 60-80, and $80-100 \mathrm{~cm}$ from the surface.

All soil samples were air-dried and ground to pass through a 2-mm sieve. Soil $\mathrm{pH}$ was measured in water at a soil:water ratio of $1: 1$ and electrical conductivity (EC) was measured in water at a 1 soil : 2 water ratio using a $\mathrm{pH}$-ion conductivity meter (Accumet model 50; Fisher Scientific, Pittsburgh, Pa.). Surface soil samples were analyzed for labile P and metals by two different extraction methods. 1) Water-soluble $\mathrm{P}$ and metals (1:10 ratio of soil to deionized water; 120-min reaction time) (Kuo, 1996);
2) Mehlich 3-extractable $\mathrm{P}, \mathrm{Cu}, \mathrm{Zn}$, and $\mathrm{Pb}$ (1:10 ratio of soil to Mehlich 3 extraction solution; 5-min reaction time) (Amacher, 1996; Mehlich, 1984). After each extraction, the suspension was centrifuged at $7500 g_{n}$ for $30 \mathrm{~min}$ and then the supernatant was passed through a 0.45- $\mu \mathrm{m}$ membrane filter. Phosphorus and metal concentrations in the extracts were determined by inductively coupled plasma atomic emission spectrometer (ICPAES, J-Y Emission Division Instruments SA, Inc., NJ). The detection limits of the ICP-AES are 2.54 (P), $1.55(\mathrm{Ca}), 5.52(\mathrm{Mg}), 3.85(\mathrm{~K}), 10.5(\mathrm{Na})$, $2.50(\mathrm{Cu}), 0.60(\mathrm{Zn}), 0.63(\mathrm{Fe}), 0.11(\mathrm{Mn}), 0.42$ $(\mathrm{Cr}), 0.61(\mathrm{Ni}), 1.96(\mathrm{~Pb}), 1.24(\mathrm{As})$, and 2.73 (Se) $\mu \mathrm{g} \cdot \mathrm{L}^{-1}$. Total $\mathrm{Cu}, \mathrm{Zn}$, and $\mathrm{P}$ contents of soil profile samples were determined using the ICP-AES after digesting $1 \mathrm{~g}$ of soil with nitric acid and perchloric acid (Reed and Martens, 1996). Statistical differences in measured variables among the sampling positions were analyzed with the SAS linear regression model procedure (SAS, 1998).

\section{Results and Discussion}

Overall variation in the surface soils. The measured soil variables varied widely among the 102 surface soil samples (Table 1). The $\mathrm{pH}$ values for all surface samples ranged from 6.18 to 8.04 with a coefficient of variation (CV) value of $5.4 \%$. The EC values varied from 49.4 to $511 \mu \mathrm{S} \cdot \mathrm{cm}^{-1}$, with the maximum value being about 10 fold of the minimum. The water-soluble $P$ and metal concentrations also varied widely, with the $\mathrm{CV}$ values ranging from $39.6 \%$ to $152 \%$. Among them, water-soluble $\mathrm{Ca}, \mathrm{Mg}, \mathrm{K}, \mathrm{Cu}, \mathrm{Fe}, \mathrm{Mn}, \mathrm{Cr}, \mathrm{Ni}, \mathrm{Pb}, \mathrm{As}$, and Se had CV values $>80 \%$. The CV values of Mehlich III-extractable $\mathrm{P}, \mathrm{Cu}, \mathrm{Zn}$, and $\mathrm{Pb}$ were between $40 \%$ and $55 \%$. High $\mathrm{CV}$ values of the water-soluble soil $\mathrm{P}$ and metal concentrations indicate a high spatial variability of the measured variables in the grove.

Correlations were significant $(p<0.05)$ for 82 of 120 soil attribute pairs (Table 2), indicating that most of the measured variables were strongly dependent. Significant correlations ( $p$ $<0.01$ ) were found between $\mathrm{EC}$ and $\mathrm{Ca}$, and $\mathrm{Mg}$; between $\mathrm{Ca}$ and $\mathrm{Cu}, \mathrm{Mg}, \mathrm{P}, \mathrm{Zn}$; between $\mathrm{Cr}$ and $\mathrm{Fe}, \mathrm{Zn}, \mathrm{As}$; between $\mathrm{Cu}$ and $\mathrm{Mg}, \mathrm{P}, \mathrm{Zn}$; between $\mathrm{Mg}$ and $\mathrm{P}, \mathrm{Zn}$; between $\mathrm{Ni}$ and $\mathrm{Zn}$; and between $\mathrm{P}$ and $\mathrm{Mn}$. Water-soluble $\mathrm{P}$ was positively correlated with all other variables except for $\mathrm{pH}$, water soluble $\mathrm{Pb}$, and $\mathrm{Se}$. All metals except for $\mathrm{Fe}, \mathrm{Pb}$, and $\mathrm{Mn}$ were positively correlated with the EC values. Water soluble $\mathrm{Cu}$ was significantly correlated with all the measured variables except for $\mathrm{pH}$ and $\mathrm{Pb}$, whereas water-soluble $\mathrm{Zn}$ was significantly correlated with all measured variables except for $\mathrm{pH}$ and $\mathrm{Na}$. The high correlations between nutrients and/or heavy metals suggest that the nutrients and/or metals accumulated in the soil had similar source (fertilizers, pesticides) and trends of accumulation and leaching in the soil.

Variations in the transect across the row. Significant variations of soil $\mathrm{pH}, \mathrm{EC}$, watersoluble $\mathrm{P}$ and metals, and Mehlich III-extractable $\mathrm{P}, \mathrm{Cu}, \mathrm{Zn}$, and $\mathrm{Pb}$ were measured in the transect perpendicular to the water furrow (Tables 3 and 4). The highest values of $\mathrm{pH}$, $\mathrm{EC}$, water-soluble $\mathrm{P}$, and all metals generally occurred in the soils under the canopies. The lowest values occurred in the soils near the water furrow (position L2) for EC, Ca, Mg, Na, $\mathrm{K}, \mathrm{P}, \mathrm{As}$, and Se, and the midway of inter-row (position L8) for most of the heavy metals (Fe, $\mathrm{Cr}, \mathrm{Cu}, \mathrm{Ni}, \mathrm{Pb}, \mathrm{Zn}$, and $\mathrm{Mn}$ ). Except for watersoluble $\mathrm{Ni}, \mathrm{As}$, and $\mathrm{Se}$, all the water-soluble

Table 2. Correlation coefficients ( $\mathrm{r}$ ) among pH, electrical conductivity (EC), and water-soluble $\mathrm{P}$ and metals $(\mathrm{n}=102)$.

\begin{tabular}{|c|c|c|c|c|c|c|c|c|c|c|c|c|c|c|c|}
\hline Variable & EC & $\mathrm{Ca}$ & $\mathrm{Cr}$ & $\mathrm{Cu}$ & $\mathrm{Fe}$ & K & $\mathrm{Mg}$ & $\mathrm{Na}$ & $\mathrm{Ni}$ & $\mathrm{P}$ & $\mathrm{Pb}$ & $\mathrm{Zn}$ & As & $\mathrm{Mn}$ & $\mathrm{Se}$ \\
\hline$\overline{\mathrm{pH}}$ & $-0.36^{* * *}$ & $-0.27^{* * *}$ & -0.06 & -0.15 & 0.01 & -0.13 & $-0.28^{* *}$ & $0.34^{* *}$ & -0.10 & -0.07 & 0.06 & -0.18 & -0.05 & 0.08 & -0.04 \\
\hline EC & & $0.79^{* * *}$ & $0.29^{* *}$ & $0.46^{* *}$ & 0.08 & $0.44^{* *}$ & $0.77^{* *}$ & $0.30^{* * *}$ & $0.31^{* *}$ & $0.64^{* *}$ & $-0.21^{*}$ & $0.49^{* *}$ & $0.21^{*}$ & 0.02 & $0.22^{*}$ \\
\hline $\mathrm{Ca}$ & & & $0.56^{* *}$ & $0.74^{* * *}$ & $0.35^{* *}$ & $0.37^{* *}$ & $0.98^{* *}$ & $0.33^{* *}$ & $0.43^{* *}$ & $0.84^{* *}$ & -0.03 & $0.78^{* *}$ & $0.41^{* *}$ & $0.30^{* *}$ & $0.36^{* *}$ \\
\hline $\mathrm{Cr}$ & & & & $0.58^{* * *}$ & $0.89^{* *}$ & $0.30^{* *}$ & $0.55^{* *}$ & 0.06 & $0.22^{*}$ & $0.53^{* *}$ & $0.47^{* *}$ & $0.78^{* *}$ & $0.71^{* *}$ & $0.61^{* *}$ & $0.40^{* *}$ \\
\hline $\mathrm{Cu}$ & & & & & $0.45^{* *}$ & $0.34^{* *}$ & $0.74^{* *}$ & $0.30^{* * *}$ & $0.45^{* *}$ & $0.74^{* *}$ & 0.17 & $0.81^{* *}$ & $0.33^{* *}$ & $0.47^{* *}$ & $0.26^{* *}$ \\
\hline $\mathrm{Fe}$ & & & & & & 0.19 & $0.36^{* *}$ & 0.00 & 0.11 & $0.36^{* *}$ & $0.53^{* *}$ & $0.61^{* *}$ & $0.76^{* *}$ & $0.65^{* *}$ & $0.30^{* *}$ \\
\hline K & & & & & & & $0.38^{* *}$ & 0.15 & 0.16 & $0.54^{* *}$ & -0.15 & $0.33^{* *}$ & 0.12 & 0.04 & $0.35^{* *}$ \\
\hline $\mathrm{Mg}$ & & & & & & & & $0.29^{* * *}$ & $0.41^{* *}$ & $0.82^{* *}$ & -0.08 & $0.74^{* *}$ & $0.44^{* *}$ & $0.23^{*}$ & $0.37^{* *}$ \\
\hline $\mathrm{Na}$ & & & & & & & & & $0.27^{* * *}$ & $0.39^{* *}$ & -0.04 & 0.19 & -0.03 & 0.15 & 0.05 \\
\hline $\mathrm{Ni}$ & & & & & & & & & & $0.33^{* * *}$ & 0.09 & $0.39^{* *}$ & 0.18 & 0.15 & 0.15 \\
\hline$P$ & & & & & & & & & & & 0.01 & $0.73^{* *}$ & $0.29^{* * *}$ & $0.38^{* *}$ & 0.33 \\
\hline $\mathrm{Pb}$ & & & & & & & & & & & & $0.37^{* * *}$ & 0.15 & $0.79^{* *}$ & 0.04 \\
\hline $\mathrm{Zn}$ & & & & & & & & & & & & & $0.47^{* *}$ & $0.68^{* *}$ & $0.36^{* *}$ \\
\hline As & & & & & & & & & & & & & & $0.30^{* *}$ & $0.40^{* *}$ \\
\hline Mn & & & & & & & & & & & & & & & $0.22^{*}$ \\
\hline
\end{tabular}


Table 3. Variations of $\mathrm{pH}$, electrical conductivity (EC), and water-soluble $\mathrm{P}$ and metals in the surface soils across the citrus row $(n=4)$.

\begin{tabular}{|c|c|c|c|c|c|c|c|c|}
\hline \multirow[b]{2}{*}{ Position } & \multirow[b]{2}{*}{$\mathrm{pH}$} & $\mathrm{EC}$ & $\mathrm{Ca}$ & $\mathrm{Mg}$ & $\mathrm{Na}$ & $\mathrm{Fe}$ & $\bar{K}$ & $\bar{P}$ \\
\hline & & $\left(\mu \mathrm{s} \cdot \mathrm{cm}^{-1}\right)$ & \multicolumn{6}{|c|}{$\left(\mathrm{mg} \cdot \mathrm{kg}^{-1}\right)$} \\
\hline$\overline{\mathrm{L} 1}$ & $6.88 \mathrm{bc}^{\mathrm{z}}$ & $147 \mathrm{bc}$ & $11.6 \mathrm{bc}$ & $1.75 \mathrm{~b}$ & $4.13 \mathrm{c}$ & $2.11 \mathrm{ab}$ & $2.29 \mathrm{bc}$ & $4.19 \mathrm{~cd}$ \\
\hline L2 & $7.37 \mathrm{a}$ & $107 \mathrm{c}$ & $4.7 \mathrm{c}$ & $0.80 \mathrm{~b}$ & $6.93 \mathrm{bc}$ & $2.43 \mathrm{ab}$ & $1.22 \mathrm{c}$ & $3.22 \mathrm{~d}$ \\
\hline L3 & $7.36 \mathrm{a}$ & 146 bc & $8.5 \mathrm{bc}$ & $1.68 \mathrm{~b}$ & $7.35 \mathrm{ab}$ & $2.55 \mathrm{ab}$ & $1.92 \mathrm{c}$ & $5.17 \mathrm{~cd}$ \\
\hline L4 & $7.35 \mathrm{a}$ & $124 \mathrm{bc}$ & $9.1 \mathrm{bc}$ & $1.78 \mathrm{~b}$ & $7.69 \mathrm{ab}$ & $3.00 \mathrm{a}$ & $1.76 \mathrm{c}$ & $6.62 \mathrm{bc}$ \\
\hline L5 & $7.18 \mathrm{ab}$ & $227 \mathrm{a}$ & $26.1 \mathrm{a}$ & $6.86 \mathrm{a}$ & $9.07 \mathrm{a}$ & $2.68 \mathrm{ab}$ & $4.00 \mathrm{ab}$ & $10.38 \mathrm{a}$ \\
\hline L6 & $7.45 \mathrm{a}$ & $212 a b$ & $21.4 \mathrm{ab}$ & $6.35 \mathrm{a}$ & $8.46 \mathrm{ab}$ & $2.07 \mathrm{ab}$ & $3.69 \mathrm{ab}$ & $8.06 \mathrm{ab}$ \\
\hline L7 & $6.72 \mathrm{c}$ & 164 bc & $8.6 \mathrm{bc}$ & $2.64 \mathrm{~b}$ & $4.61 b c$ & $0.88 \mathrm{~b}$ & $4.39 \mathrm{a}$ & $5.41 \mathrm{~cd}$ \\
\hline \multirow[t]{3}{*}{ L8 } & $6.66 \mathrm{c}$ & $181 \mathrm{bc}$ & $10.9 \mathrm{bc}$ & $3.69 \mathrm{ab}$ & $4.21 \mathrm{c}$ & $0.98 \mathrm{~b}$ & $3.28 \mathrm{ab}$ & $4.17 \mathrm{~cd}$ \\
\hline & $\mathrm{Mn}$ & $\mathrm{Cu}$ & $\mathrm{Zn}$ & $\mathrm{Pb}$ & $\mathrm{Ni}$ & As & $\mathrm{Se}$ & $\mathrm{Cr}$ \\
\hline & \multicolumn{3}{|c|}{$\left(\mathrm{mg} \cdot \mathrm{kg}^{-1}\right)$} & \multicolumn{5}{|c|}{$\left(\mu \mathrm{g} \cdot \mathrm{kg}^{-1}\right)$} \\
\hline$\overline{\mathrm{L} 1}$ & $0.83 \mathrm{ab}$ & $1.21 \mathrm{bc}$ & $0.47 \mathrm{ab}$ & $24.4 \mathrm{ab}$ & $10.2 \mathrm{a}$ & $7.06 \mathrm{a}$ & $6.15 \mathrm{a}$ & $8.4 \mathrm{bc}$ \\
\hline L2 & $1.16 \mathrm{ab}$ & $1.17 \mathrm{bc}$ & $0.38 \mathrm{ab}$ & $57.8 \mathrm{a}$ & $10.7 \mathrm{a}$ & $3.37 \mathrm{a}$ & $6.61 \mathrm{a}$ & $8.4 \mathrm{bc}$ \\
\hline L3 & $1.06 \mathrm{ab}$ & $1.34 \mathrm{ab}$ & $0.42 \mathrm{ab}$ & $67.1 \mathrm{a}$ & $11.6 \mathrm{a}$ & $1.11 \mathrm{a}$ & $2.72 \mathrm{a}$ & $11.6 \mathrm{ab}$ \\
\hline L4 & $1.27 \mathrm{ab}$ & $1.63 \mathrm{a}$ & $0.40 \mathrm{ab}$ & $71.7 \mathrm{a}$ & $14.1 \mathrm{a}$ & $7.67 \mathrm{a}$ & $10.45 \mathrm{a}$ & $12.9 \mathrm{a}$ \\
\hline L5 & $1.32 \mathrm{a}$ & $1.49 \mathrm{a}$ & $0.52 \mathrm{a}$ & $27.0 \mathrm{ab}$ & $18.5 \mathrm{a}$ & $10.93 \mathrm{a}$ & $19.40 \mathrm{a}$ & $12.2 \mathrm{a}$ \\
\hline L6 & $0.83 \mathrm{ab}$ & $1.05 \mathrm{bc}$ & $0.51 \mathrm{a}$ & $26.6 \mathrm{ab}$ & $21.0 \mathrm{a}$ & $8.22 \mathrm{a}$ & $18.40 \mathrm{a}$ & $10.0 \mathrm{bc}$ \\
\hline L7 & $0.06 \mathrm{~b}$ & $0.54 \mathrm{bc}$ & $0.28 \mathrm{~b}$ & $1.32 \mathrm{~b}$ & $12.9 \mathrm{a}$ & $9.98 \mathrm{a}$ & $12.50 \mathrm{a}$ & $5.0 \mathrm{bc}$ \\
\hline L8 & $0.09 \mathrm{~b}$ & $0.47 \mathrm{c}$ & $0.26 \mathrm{~b}$ & $2.29 \mathrm{~b}$ & $9.9 \mathrm{a}$ & $8.02 \mathrm{a}$ & $8.91 \mathrm{a}$ & $4.8 \mathrm{c}$ \\
\hline
\end{tabular}

${ }^{2}$ Mean values for each variable with the same letter (s) are not different at $p=0.05$.

Table 4. Variations of Mehlich III-extractable $\mathrm{Cu}, \mathrm{P}, \mathrm{Pb}$, and $\mathrm{Zn}$ in the surface soils across the citrus row $(\mathrm{n}=4)$.

\begin{tabular}{lcccc}
\hline & \multicolumn{4}{c}{ Mean concn $\left(\mathrm{mg}^{\circ} \mathrm{kg}^{-1}\right)$} \\
\cline { 2 - 5 } Position & $\mathrm{Cu}$ & $\mathrm{P}$ & $\mathrm{Pb}$ & $\mathrm{Zn}$ \\
\hline L1 & $55.9 \mathrm{bc}^{2}$ & $81.2 \mathrm{c}$ & $2.53 \mathrm{bc}$ & $36.8 \mathrm{bc}$ \\
L2 & $109.7 \mathrm{a}$ & $67.1 \mathrm{c}$ & $3.92 \mathrm{ab}$ & $35.5 \mathrm{bc}$ \\
L3 & $111.1 \mathrm{a}$ & $86.5 \mathrm{c}$ & $4.38 \mathrm{a}$ & $39.5 \mathrm{ab}$ \\
L4 & $115.1 \mathrm{a}$ & $173.4 \mathrm{~b}$ & $4.51 \mathrm{a}$ & $34.4 \mathrm{bc}$ \\
L5 & $110.6 \mathrm{a}$ & $300.6 \mathrm{a}$ & $2.87 \mathrm{bc}$ & $52.3 \mathrm{a}$ \\
L6 & $62.6 \mathrm{~b}$ & $189.8 \mathrm{~b}$ & $3.26 \mathrm{bc}$ & $47.1 \mathrm{ab}$ \\
L7 & $44.7 \mathrm{bc}$ & $85.7 \mathrm{c}$ & $1.71 \mathrm{c}$ & $44.7 \mathrm{ab}$ \\
L8 & $28.6 \mathrm{c}$ & $58.6 \mathrm{c}$ & $1.71 \mathrm{c}$ & $22.4 \mathrm{c}$ \\
\hline
\end{tabular}

${ }^{2}$ Mean values for each variable with the same letter (s) are not different at $p=0.05$.

Table 5. Variations of $\mathrm{pH}$, electrical conductivity (EC), and water-soluble $\mathrm{P}$ and metals in the surface soils along the citrus row $(\mathrm{n}=17)$.

\begin{tabular}{|c|c|c|c|c|c|c|c|c|}
\hline \multirow[b]{2}{*}{ Position } & \multirow[b]{2}{*}{$\mathrm{pH}$} & \multirow{2}{*}{$\begin{array}{c}\mathrm{EC} \\
\left(\mu \mathrm{s} \cdot \mathrm{cm}^{-1}\right)\end{array}$} & $\mathrm{Ca}$ & $\mathrm{Mg}$ & $\mathrm{Na}$ & $\mathrm{Fe}$ & $\mathrm{K}$ & $P$ \\
\hline & & & \multicolumn{6}{|c|}{$\left(\mathrm{mg} \cdot \mathrm{kg}^{-1}\right)$} \\
\hline$\overline{\mathrm{A}}$ & $7.36 \mathrm{a}^{\mathrm{z}}$ & $209 a$ & $22.5 \mathrm{a}$ & $6.10 \mathrm{a}$ & $6.52 \mathrm{a}$ & $2.74 \mathrm{a}$ & $4.35 \mathrm{a}$ & $9.22 \mathrm{a}$ \\
\hline B & $7.34 \mathrm{a}$ & $115 \mathrm{~b}$ & $9.7 \mathrm{~b}$ & $2.95 \mathrm{~b}$ & $5.92 \mathrm{a}$ & $3.52 \mathrm{a}$ & $1.65 \mathrm{~b}$ & $4.88 \mathrm{~b}$ \\
\hline \multirow[t]{3}{*}{$\mathrm{C}$} & $7.08 \mathrm{~b}$ & $104 \mathrm{~b}$ & $6.8 \mathrm{~b}$ & $1.90 \mathrm{~b}$ & $4.51 \mathrm{~b}$ & $2.70 \mathrm{a}$ & $1.90 \mathrm{ab}$ & $4.75 \mathrm{~b}$ \\
\hline & $\mathrm{Mn}$ & $\mathrm{Cu}$ & $\mathrm{Zn}$ & $\mathrm{Pb}$ & $\mathrm{Ni}$ & As & $\mathrm{Se}$ & $\mathrm{Cr}$ \\
\hline & \multicolumn{3}{|c|}{$\left(\mathrm{mg} \cdot \mathrm{kg}^{-1}\right)$} & \multicolumn{5}{|c|}{$\left(\mu \mathrm{g} \cdot \mathrm{kg}^{-1}\right)$} \\
\hline$\overline{\mathrm{A}}$ & $0.96 \mathrm{a}$ & $2.04 \mathrm{a}$ & $0.54 \mathrm{a}$ & $14.7 \mathrm{a}$ & $6.32 \mathrm{a}$ & $17.02 \mathrm{a}$ & $10.78 \mathrm{a}$ & $13.5 \mathrm{a}$ \\
\hline B & $0.95 \mathrm{a}$ & $0.78 \mathrm{~b}$ & $0.35 \mathrm{~b}$ & $45.0 \mathrm{a}$ & $5.38 \mathrm{a}$ & $21.32 \mathrm{a}$ & $13.22 \mathrm{a}$ & $12.0 \mathrm{a}$ \\
\hline $\mathrm{C}$ & $0.74 \mathrm{a}$ & $0.74 \mathrm{~b}$ & $0.31 \mathrm{~b}$ & $36.8 \mathrm{a}$ & $3.32 \mathrm{a}$ & $8.09 \mathrm{a}$ & $10.12 \mathrm{a}$ & $8.7 \mathrm{a}$ \\
\hline
\end{tabular}

${ }^{2}$ Mean values for each variable with the same letter (s) are not different at $p=0.05$.

Table 6. Variations of Mehlich III-extractable $\mathrm{Cu}, \mathrm{P}, \mathrm{Pb}$, and $\mathrm{Zn}$ in the surface soils along the citrus row $(\mathrm{n}=17)$.

\begin{tabular}{lcccc}
\hline & \multicolumn{4}{c}{ Mean concn $\left(\mathrm{mg}^{\mathrm{k}} \mathrm{kg}^{-1}\right)$} \\
\cline { 2 - 5 } Position & $\mathrm{Cu}$ & $\mathrm{P}$ & $\mathrm{Pb}$ & $\mathrm{Zn}$ \\
\hline $\mathrm{A}$ & $82.5 \mathrm{a}^{\mathrm{z}}$ & $208.8 \mathrm{a}$ & $2.45 \mathrm{a}$ & $48.3 \mathrm{a}$ \\
$\mathrm{B}$ & $54.4 \mathrm{~b}$ & $97.9 \mathrm{~b}$ & $3.26 \mathrm{a}$ & $24.8 \mathrm{~b}$ \\
$\mathrm{C}$ & $56.8 \mathrm{~b}$ & $111.3 \mathrm{~b}$ & $3.31 \mathrm{a}$ & $20.0 \mathrm{~b}$ \\
\hline${ }^{2}$ Mean values for each variable with the same letter $(\mathrm{s})$ are not different at $p=0.05$.
\end{tabular}

components were significantly different among the eight sampling positions (L1, L2, L3, L4, L5, L6, L7, and L8). In addition, the highest values of Mehlich III-extractable $\mathrm{Cu}, \mathrm{P}, \mathrm{Pb}$, and $\mathrm{Zn}$ also occurred in the soils under the canopies (L3, L4, L5; Table 4), whereas the lowest values generally occurred at the midway of the interrow (position L8). Higher concentrations of water-soluble and Mehlich III extractable P and considerable portion of the rainfall, and thus reduced rain dropping on the soil under the canopy. Therefore, leaching of $\mathrm{P}$ and metals from soil-applied fertilizers under the canopy was less pronounced than for the other spaces. A study by Alva et al. (1999) using 25-year-old Valencia orange (Citrus sinensis L. Osbeck) showed that the amounts of precipitation under the canopy were $47 \%$ to $94 \%$ of the incident rainfall. Parkin and Codling (1990) also observed that corn plants could intercept and channel $19 \%$ to $42 \%$ of the total rainfall during a storm event, which could reduce the leaching of fertilizer under the canopy to groundwater. In addition, the higher concentrations of $\mathrm{P}$ and heavy metals under the canopy could be also due to increased leaf litters under the canopy. Tree can acquire nutrients from the spaces between the trees, and then concentrate the nutrients under the canopy (Davenport et al., 1996; Mcdaniel and Graham, 1992). The organic materials often contained more $\mathrm{P}$ and heavy metals than inorganic components, and would reduce metal leaching from the sandy soils. The application of partial $\mathrm{P}$ through the emitters was also partially responsible for the higher $\mathrm{P}$ concentration under the canopy.

The decreased water-soluble $\mathrm{Ca}, \mathrm{Mg}$, $\mathrm{Na}, \mathrm{K}$, and $\mathrm{P}$ concentrations in the soil near the water furrow were probably due to the stronger surface runoff near the water furrow. Lower water-soluble heavy metals in the soil in the midway of inter-row were due to great leaching and low input of the metals. Since micronutrients were applied by foliar spray, potential foliar runoff of heavy metals induced by foliar application of micronutrients was a possible factor for concentrations of heavy metals under the canopy.

Variations along the row. $\mathrm{pH}, \mathrm{EC}$, and water-soluble $\mathrm{Ca}, \mathrm{P}, \mathrm{Cu}$, and $\mathrm{Zn}$ concentrations of 51 surface soils were measured every $1.33 \mathrm{~m}$ along a 68-m-long citrus row. All the measured variables varied over a short distance. The difference in $\mathrm{pH}$ values between maximum and minimum along the row was $\approx 1.5$ units. The maximum values of $\mathrm{EC}$, and water-soluble $\mathrm{Ca}, \mathrm{P}, \mathrm{Cu}$, and $\mathrm{Zn}$ were 9.1, 46.1, 8.3, 53.2, and 7.6-fold, respectively, of their minimum values (data not shown). The variation of EC, and water-soluble $\mathrm{Ca}$ and $\mathrm{Cu}$ were greater than that of water-soluble $\mathrm{P}$ and $\mathrm{Zn}$.

Tables 5 and 6 show statistical results of $\mathrm{pH}$, EC, water-soluble P and metals, and Mehlich III-extractable $\mathrm{P}, \mathrm{Cu}, \mathrm{Zn}$, and $\mathrm{Pb}$ when all the 51 surface soil samples were categorized into three groups (positions A, B, and C) based on their sampling positions. The differences in the $\mathrm{pH}, \mathrm{EC}$, water-soluble $\mathrm{Ca}, \mathrm{Mg}, \mathrm{Na}, \mathrm{K}, \mathrm{P}, \mathrm{Cu}$, and $\mathrm{Zn}$, and Mehlich III extractable $\mathrm{Zn}, \mathrm{P}$, and $\mathrm{Cu}$ were significant among the three positions. The highest values of all measured variables except for water-soluble $\mathrm{Fe}, \mathrm{Pb}$, As, and $\mathrm{Se}$, and Mehlich III extractable $\mathrm{Pb}$ occurred at position A. This position was located at the north side of the citrus tree, close to the emitter, whereas the lowest values for most of the measured variables, including $\mathrm{pH}, \mathrm{EC}$, water-soluble $\mathrm{Ca}, \mathrm{Mg}, \mathrm{Na}, \mathrm{K}, \mathrm{P}, \mathrm{Cr}, \mathrm{Cu}, \mathrm{Ni}, \mathrm{Zn}, \mathrm{As}, \mathrm{Mn}$, and Mehlich III extractable $\mathrm{Cu}$ and $\mathrm{Zn}$ occurred at position C. Significant higher values of the EC, 

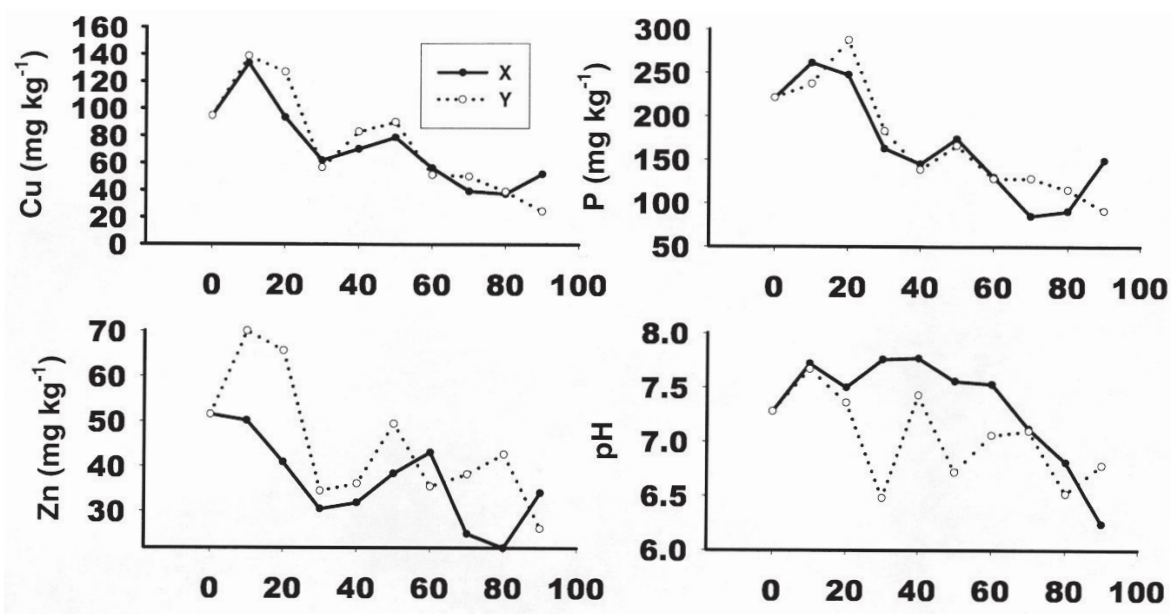

\section{Distance from microjet (cm)}

Fig. 2. Variations of Mehlich III-extractable $\mathrm{P}, \mathrm{Zn}$, and $\mathrm{Cu}$ and $\mathrm{pH}$ in the soils near the emitter as a function of distance $(\mathrm{X}=$ along the row, $\mathrm{Y}=$ perpendicular to the row.

and water-soluble $\mathrm{Ca}, \mathrm{Mg}, \mathrm{Na}, \mathrm{P}, \mathrm{Cu}$, and $\mathrm{Zn}$ probably resulted from a long-term fertigation that supplied and increased the metals in the soils around the position A.

Small-scale variations near emitter. High variability of selected variables occurred near an emitter (Fig. 2). The variations of Mehlich III extractable $\mathrm{P}, \mathrm{Cu}$, and $\mathrm{Zn}$ were greater than
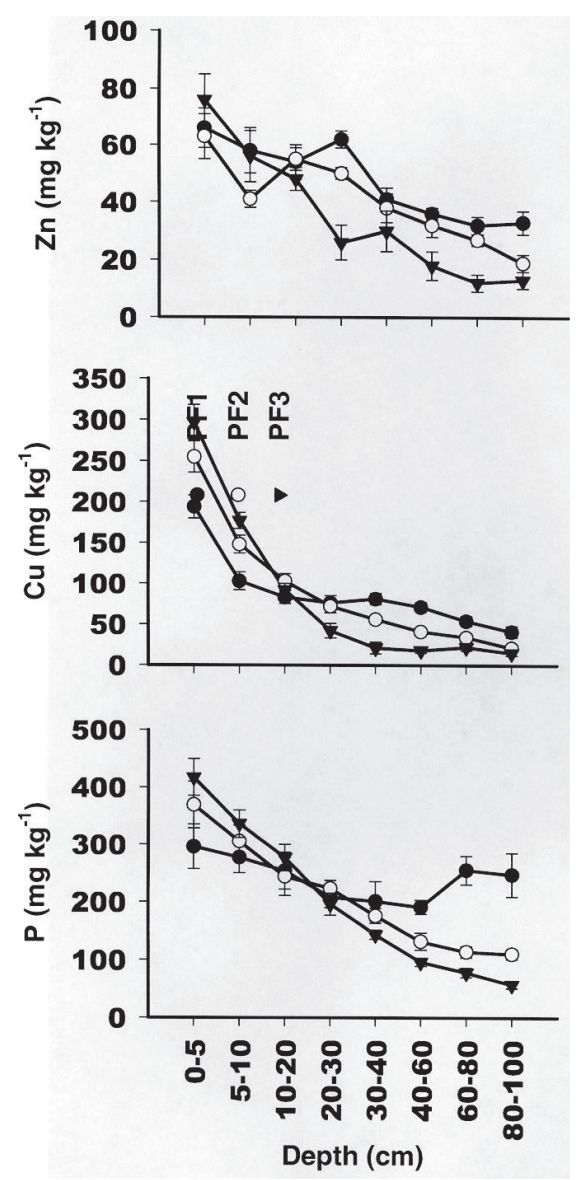

Fig. 3. Vertical variations of total $\mathrm{P}, \mathrm{Cu}$, and $\mathrm{Zn}$ in the soil profiles collected from different positions. $\mathrm{PF} 1=$ near the water furrow, $\mathrm{PF} 2=$ modway of the interneighboring tree, PF3 = under the canopy. variation of $\mathrm{pH}$. Higher Mehlich III extractable $\mathrm{P}, \mathrm{Cu}$, and $\mathrm{Zn}$ occurred in the soils within 0 to $20 \mathrm{~cm}$ distance from the emitter. The variations were probably due to uneven distribution of irrigation by the emitter. The soil in the area within 0 to $20 \mathrm{~cm}$ distance from the emitter, receiving more irrigation water than outside with distance of 20 to $90 \mathrm{~cm}$ from the emitter, had more $\mathrm{P}$ accumulation. In addition, being closer to citrus tree trunk, the soil in the area within 0 to $20 \mathrm{~cm}$ distance from the emitter also received more heavy metals from trunk flow than other areas.

Vertical distribution of phosphorus, copper, and zinc. Profile distributions of contaminants in soils can trace migration of the contaminants (Cassagne et al., 2000; Maskall et al., 1996). Significant variations of total $\mathrm{P}, \mathrm{Cu}$, and $\mathrm{Zn}$ concentrations occurred among the three sampling locations. Generally, total $\mathrm{P}, \mathrm{Cu}$ and $\mathrm{Zn}$ were the highest in the surface soils ( 0 to 5 $\mathrm{cm}$ ) and decreased gradually downward (Fig. 3). Total $\mathrm{P}, \mathrm{Cu}$, and $\mathrm{Zn}$ concentrations in the soils of 0 to $10 \mathrm{~cm}$ depth were higher in the PF3 than the PF1 and PF2. In contrast, for the soils at the 20 to $100 \mathrm{~cm}$ depth, the total $\mathrm{P}, \mathrm{Cu}$, and $\mathrm{Zn}$ concentrations were higher in PF1 and $\mathrm{PF} 2$ than $\mathrm{PF} 3$, indicating that $\mathrm{P}, \mathrm{Cu}$, and Zn downward movement in the soils near the water furrow or midway of inter-neighboring trees was more significant than those under the canopies. The extent of $\mathrm{P}, \mathrm{Cu}$, and $\mathrm{Zn}$ downward movement was in the order of PF1 > PF2 > PF3. These results suggest that application of fertilizers to site under the canopy rather than the spaces between the trees could minimize leaching losses of $\mathrm{P}$ and metals.

\section{Conclusions}

Labile $\mathrm{P}$ and metals in the soil under citrus production were characterized by a high spatial variability, even within a very short distance, as indicated by high $\mathrm{CV}$ values. Across the row, the values of $\mathrm{pH}, \mathrm{EC}$, water-soluble $\mathrm{P}$, and all metals were the highest in the soils under the canopies, and the lowest in the soils near the water furrow or the midway of inter-row.
Along the row, the highest values of most measured variables occurred at the location close to the emitter where $\mathrm{P}$ and metals were partially supplied by the fertigation. Most of the measured variables were strongly spatially dependent. Phosphorus, $\mathrm{Cu}$, and $\mathrm{Zn}$ downward movement in the soil was more significant near the water furrow or midway of interneighboring trees than under the canopies. The downward movement of $\mathrm{P}, \mathrm{Cu}$, and $\mathrm{Zn}$ in the soils was more significant in the soils in open areas (near the water furrow and midway of inter-neighboring trees) than those under the canopies. The spatial variation of soil labile $\mathrm{P}$ and metals is a reflection of spatial variation in both fertigation and rain-induced leachings and merits great attention in the sampling and interpretation of soil analysis data for citrus production systems. These results also suggest that application of fertilizers to site under the canopy rather than the spaces between the trees could minimize leaching losses of $\mathrm{P}$ and metals.

\section{Literature Cited}

Alva, A.K. 1992. Micronutrients status of Florida soils under citrus production. Commun. Soil Sci. Plant Anal. 23:2493-2510.

Alva, A.K., O. Prakash, A. Fares, and A.G. Hornsby. 1999. Distribution of rainfall and soil moisture content in the soil profile under citrus tree canopy and at the dripline. Irr. Sci. 18:109-115.

Amacher, M.C. 1996. Nickel, Cadmium, and Lead p. 739-768. In: D.L. Spark (ed.). Methods of soil analysis, Part 3: Chemical methods. SSSA Book Ser. 5, SSSA-ASA, Madison, Wis.

Belsky, A.J., S.M. Mwonga, R.G. Amundson, J.M Duxbury, and A.R. Ali. 1993. Comparative effects of isolated trees on their undercanopy environments in high- and low-rainfall savannas. J. Appl. Ecol. 30:143-155.

Berger, T.W. and G. Glatzel. 1998. Canopy leaching dry deposition, and cycling of calcium in Austrian oak stands as a function of calcium availability and distance from a lime quarry. Can. J. For. Res. 28:1388-1397.

Callaway, R.M. 1990. Effects of soil water distribution on the lateral root development of three species in California oaks. Amer. J. Bot. 77:1469-1475.

Cassagne, N., M. Remaury, T. Gauquelin, and A Fabre. 2000. Forms and profile distribution of soil phosphorus in alpine Inceptisols and Spodosols (Pyrenees, France). Geoderma. 95:161-172.

Challinor, D. 1968. Alteration of surface soil characteristics by four tree species. Ecol. 49:286-290.

Davenport, D.W., B.P. Wilcox, and D.D. Breshears 1996. Soil morphology of canopy and intercanopy sites in a pinon-juniper woodland. Soil Sci. Soc. Amer. J. 60:1881-1887.

Dolan, M.S., R.H. Dowdy, and J.A. Lamb. 2001 Redirection of precipitation by a corn canopy and related soil water status. Commun. Soil Sci. Plant Anal. 32:739-750.

Heckrath, G.,P.C. Brookes, P.R. Poulton, and K.W.T Goulding. 1995. Phosphorus leaching from soils containing different phosphorus concentrations in the Broadbalk experiment. J. Environ. Qual. 24:904-910.

Hook, P.B., W.K. Lauenroth, and I.C. Burke. 1994 Spatial patterns of roots in a semiarid grassland: abundance of canopy openings regeneration gaps. J. Ecol. 82:485-494.

Kuo, S. 1996. Phosphorus, p. 869-919. In: D.L. Spark 
(ed.). Methods of soil analysis, Part 3: Chemical methods. SSSA Book Ser. 5, SSSA-ASA, Madison, Wis.

Maskall, J., K. Whitehead, C. Gee, and I. Thornton. 1996. Long-term migration of metals at historical smelting sites. Appl. Geochem. 11:43-51.

Mcdaniel, P.A. and R.C. Graham. 1992. Organiccarbon distributions in shallow of pinyon juniper woodlands. Soil Sci. Soc. Amer. J. 56:499-504.

Mehlich, A. 1984. Mehlich No. 3 soil test extractant: A modification of Mehlich No.2 extractant. Commun. Soil Sci. Plant Anal. 15:1409-1416.

Moody, A. and J.A. Jones. 2000. Soil response to canopy position and feral pig disturbance beneath Quercus agrifolia on Santa Cruz island, California. Appl. Soil Ecol. 14:269-281.
Moore, Jr., P.A, T.C. Daniel, J.T. Gilmour, B.R. Shreve, D.R. Edwards, and B.H. Wood. 1998 Decreasing metal runoff from poultry litter with aluminum sulfate. J. Environ. Qual. 27:92-99.

Ostertag, R. 1998. Belowground effects of canopy gaps in a tropical forest. Ecology 79:1294 1304.

Parker, V.T., and C.H. Muller. 1982. Vegetation and environmental changes beneath isolated live oak trees (Quercus agrifolia) in a California annual grassland. Amer. Midl. Natural. 107:69-81.

Parkin, T.B., and E.E. Codling. 1990. Rainfal distribution under a corn canopy: Implications for managing agri-chemicals. Agron. J. 22:1166-1169.

Reed, S.T., and D.C. Martens, 1996. Copper and zinc. p. 703-722.In:D.L. Spark (ed.). Methods of soil analysis, Part 3: Chemical methods. SSSA Book Ser. 5, SSSA-ASA. Madison, Wis.

Saffigna, P.G., C.B. Tanner, and D.R. Keeney. 1976 Non-uniform infiltration under potato canopies caused by interception, stemflow, and hilling. Agron. J. 60:337-342.

SAS. 1998. SAS user's guide: Statistics; SAS Inst., Cary, N.C.

Sharpley, A.N. 1995. Dependence of runoff phosphorus on extractable soil phosphorus. J. Environ. Qual. 24:920-926.

Stanley, C.D., P.R. Gilreath, J.D. Creighton, B.L. McNeal, W.D. Graham, and G. Alverio. 1995. Nutrient-loss trends for vegetables and citrus fields in west-central Florida: II. Phosphate. J. Environ. Qual. 24:101-106. 